\title{
EL PAPEL DE LA AGRICULTURA FAMILIAR EN REGIONES AGRARIAS FRÁGILES Y EN EL DESARROLLO RURAL. LA CORDILLERA DEL TENTZO, PUEBLA, MÉXICO
}

\section{THE ROLE OF FAMILY AGRICULTURE IN FRAGILE AGRARIAN REGIONS AND IN RURAL DEVELOPMENT: THE TENTZO MOUNTAIN RANGE, PUEBLA, MÉXICO}

\author{
Javier Ramírez-Juárez
}

\begin{abstract}
Colegio de Postgraduados, Campus Puebla. Km 125.5 Carretera Federal México-Puebla, Santiago Momoxpan, San Pedro Cholula, Puebla, México. 72760. (rjavier@colpos.mx)
\end{abstract}

\section{RESUMEN}

Este trabajo aborda el papel de la agricultura familiar en el desarrollo rural de la cordillera del Tentzo, Puebla, región desfavorecida, ambientalmente frágil, pobre y de emigración. El objetivo fue analizar un doble proceso; por una parte, la trayectoria agraria que la ha configurado como una región de reproducción social de fuerza de trabajo y pobreza y, por otra, el papel de la agricultura de subsistencia en el desarrollo rural en sus funciones productivas y la adopción a esquemas de pluriactividad y complementariedad de ingresos económicos. La inserción en los mercados laborales de los miembros de los hogares campesinos cambió la base agraria de su reproducción social, pero sin abandonar la agricultura, pues el mercado laboral es flexible, inestable e insuficiente, por lo cual integran las actividades agrícolas y no agrícolas. Los hogares campesinos y su permanencia regional son resultado de las transformaciones agrarias y los procesos vinculados con el mercado de trabajo. Un sistema agropecuario sustentable puede contribuir al desarrollo rural, regulando la fuerza de trabajo, la seguridad alimentaria y el cuidado de los recursos y el medio ambiente.

Palabras clave: exclusión social, mercados laborales, pluriactividad, pobreza rural, sistema agrario.

\section{INTRODUCCIÓN}

$\mathrm{L}$ a cordillera del Tentzo, Puebla, es una región ambientalmente frágil y con pobreza, donde la agricultura familiar encuentra dificultades para mantener sus condiciones de reproducción socioeconómica, lo cual obliga a sus miembros a la pluriactividad con la inserción en mercados laborales. Las actividades

* Autor responsable * Author for correspondence.

Recibido: septiembre, 2013. Aprobado: noviembre, 2013.

Publicado como ARTÍCULO en ASyD 10: 459-477. 2013.

\section{Abstract}

This study addresses the role of family agriculture in rural development of the Tentzo Mountain Range, Puebla, a disadvantaged, environmentally fragile, poor and with migration, region. The objective was to analyze a double process; on the one hand, the agrarian trajectory that has made it into a region of social reproduction of workforce and poverty; and, on the other hand, the role of subsistence agriculture in rural development for its productive functions, and the adoption of pluriactivity schemes and complementarity of economic income. The insertion into labor markets of members of peasant households changed the agrarian base of their social reproduction, although without abandoning agriculture, since the labor market is flexible, unstable and insufficient, integrated by agricultural and non-agricultural activities. The peasant households and their regional permanence are the result of agrarian transformations and processes linked to the labor market. A sustainable agricultural and livestock system can contribute to rural development, regulating the workforce, food security and the care for resources and the environment.

Key words: social exclusion, labor markets, pluriactivity, rural poverty, agrarian system.

\section{INTRODUCTION}

The Tentzo Mountain Range, in Puebla, is an environmentally fragile region with poverty, where family agriculture finds difficulties to maintain its conditions of socioeconomic reproduction, forcing its members to turn to pluriactivity with the insertion into labor markets. The work activities that they gain access to are generally precarious, flexible and with low pay; and processes of labor inclusion/exclusion are generated, 
laborales a las que acceden son por lo general precarias, flexibles y de baja remuneración, generándose procesos de inclusión/exclusión laboral, condicionados por las redes de capital al ser poblaciones y territorios que no tienen interés para la dinámica del capitalismo global (Castells, 2006). Así, el trabajo tuvo como objetivo analizar un doble proceso; por una parte, la trayectoria agraria de la cordillera del Tentzo, que la ha configurado en una región de reproducción social de fuerza de trabajo y pobreza $y$, por otra parte, el papel de la agricultura de subsistencia en el desarrollo rural en sus funciones productivas y adopción a esquemas de pluriactividad y complementariedad de ingresos económicos.

Las interpretaciones sobre las transformaciones rurales recientes, en el marco del modelo neoliberal del campo mexicano y latinoamericano, enfatizan la disminución de los ingresos agrarios de los hogares campesinos y la profundización de la emigración, de la pobreza y de la pluriactividad. Se valora que la pluriactividad de las familias u hogares campesinos es una tendencia que se profundiza (Kay, 2007), al igual que la desagrarización ${ }^{1}$ de la economía rural (Escalante et al., 2007; Carton, 2009; Pérez, 2001 y 2005). En la perspectiva de Carton de Grammont (2007), las transformaciones son tan profundas que parece justificado hablar del tránsito de un mundo agrario dominado por la producción agropecuaria hacia una sociedad rural más diversificada.

En congruencia con las transformaciones rurales, se han planteado nuevos enfoques de desarrollo rural, cuyo eje no es necesariamente la agricultura, y que tienen como objetivo superar la pobreza rural incorporando, por ejemplo, el papel de las ciudades intermedias y las interacciones entre el núcleo urbano y su hinterland agrícola (Rello, 1998; Link, 2001). Schejtman (1999) y Dirven (2004) proponen incorporar la relación urbanorural y el empleo rural no agrícola (ERNA) en las estrategias de desarrollo rural, así como fomentar el ERNA al contribuir a estabilizar los ingresos, compensando la estacionalidad de la producción y del empleo agrícola. A partir de reconocer la multifuncionalidad del territorio, De Janvry y Sadoulet (2004) consideran nuevas oportunidades para la reducción de la pobreza rural con el enfoque territorial del desarrollo rural, considerando la expansión de la "nueva agricultura", la industrialización de las áreas rurales, el incremento de la integración económica entre las áreas rurales y urbanas; el avance en la descentralización gubernamental; el aumento de las conditioned by the networks of capital, since these are populations and territories of no interest to the dynamics of global capitalism (Castells, 2006). Thus, this study had the objective of analyzing a double process; on the one hand, the agrarian trajectory of the Tentzo Mountain Range, which has configured it into a region of social reproduction of workforce and poverty; and, on the other hand, the role of subsistence agriculture in rural development in its productive functions, and the adoption of pluriactivity schemes and complementarity of economic income.

Interpretations about recent rural transformations, within the framework of the Neoliberal model of the Mexican and Latin American countryside, emphasize the decrease in agrarian income of peasant households and the deepening of migration, poverty and pluriactivity. It is assessed that pluriactivity in the peasant families or households is a trend that is deepening (Kay, 2007), just like deagrarization ${ }^{1}$ of the rural economy (Escalante et al., 2007; Carton, 2009; Pérez, 2001 and 2005). Under the perspective of Carton (2007), the transformations are so deep that it seems justified to speak of the transit from an agrarian world dominated by agricultural and livestock production to a more diversified rural society.

In congruence with the rural transformations, new approaches for rural development have been suggested, whose axis is not necessarily linked to agriculture, and which have the objective of overcoming rural poverty by incorporating, for example, the role of intermediate cities and the interactions between the urban nucleus and its agricultural hinterland (Rello, 1998; Link, 2001). Schejtman (1999) and Dirven (2004) suggest incorporating the urban-rural relationship and non-agricultural rural employment (NARE) into the strategies for rural development, as well as fostering NARE by contributing to stabilize income, compensating the seasonality of production and agricultural employment. From recognizing the multifunctionality of the territory, De Janvry and Sadoulet (2004) consider new opportunities for the reduction of rural poverty with the territorial rural development approach, taking into account the expansion of "new agriculture", the industrialization of rural areas, the increase of economic integration between rural and urban areas; the advance in governmental decentralization; the increase of civil society organizations in rural areas; and, the greater 
organizaciones de la sociedad civil en áreas rurales; y la mayor demanda de servicios medioambientales. Por su parte, Schejtman y Berdegué (2008) sostienen que las políticas públicas de desarrollo rural se deben desagriculturizar como un paso de las tareas de territorializar las inversiones rurales. Argumentan en que esto no debe significar abandonar a la agricultura, pero sí dejar de hacerlo a expensas de desatender a los demás sectores que forman parte de la economía del territorio.

Los enfoques anteriores ofrecen una ampliación de las perspectivas del desarrollo rural en congruencia con la pérdida de importancia relativa de la agricultura, que pueden ser evaluadas a partir de los recursos económicos y de la inversión pública y privada que demanda un desarrollo rural incluyente. Empero, el planteamiento que aquí se sustenta es que la agricultura ha de ser evaluada en su aporte productivo y territorial en el desarrollo rural; que un sesgo antiagrario en las políticas de desarrollo rural puede desaprovechar potencialidades productivas agrarias, además de vulnerar la producción de alimentos y seguridad alimentaria en un contexto de inestabilidad de los precios internacionales de los alimentos.

Para el cotejo del planteamiento se abordó la trayectoria agraria de la cordillera del Tentzo, sus características ambientales, las actividades económicas y el poblamiento para identificar los elementos que la han configurado en una región de reproducción social de fuerza de trabajo y pobreza. Esta elaboración se realizó a partir de la revisión de fuentes bibliográficas, históricas, estadísticas y de recorridos de campo por la región. En un segundo momento se realizó trabajo de campo en el verano de 2009, bajo un método cualitativo con el objetivo de abordar el papel de la agricultura de subsistencia en el desarrollo rural y adopción a esquemas de pluriactividad. Se realizaron entrevistas semiestructuradas a autoridades ejidales y líderes de las comunidades, y observación participante con la finalidad de captar y analizar las relaciones entre las actividades económicas de los hogares campesinos. A partir de ello se identificó y aplicó una encuesta a 78 hogares campesinos, que por su disposición y conocimiento de la situación a indagar fueron seleccionados bajo un muestreo opinático (Ruiz, 1999), para proporcionar información sobre las variables y las relaciones de estudio. Los datos fueron procesados con el programa SPSS. Se sistematizó y analizó la información en función de las variables y las relaciones de estudio planteadas en este documento. demand for environmental services. In their turn, Schejtman and Berdegué (2008) argue that rural development public policies must be deagriculturized as a step in the task of territorializing rural investments. They say that this should not mean abandoning agriculture, but rather ceasing to do it at the expense of neglecting the other sectors that are part of the economy of the territory.

These approaches offer a broadening of the perspectives in rural development, in congruence with the loss of agriculture's relative importance, which can be evaluated from economic resources and the public and private investment that an inclusive rural development demands. Nevertheless, the proposal sustained here is that agriculture should be evaluated by its productive and territorial contribution to rural development; that an anti-agrarian bias in policies for rural development can lose out on agrarian productive potentialities, in addition to endangering food production and food security within a context of instability of international food prices.

In order to compare the proposal, the agrarian trajectory of the Tentzo Mountain Range was addressed, its characteristics, economic activities and population, to identify the elements that have configured it into a region of social reproduction of workforce and poverty. This elaboration was performed from the examination of bibliographic, historic and statistical sources, and field visits in the region. At a second moment field work was carried out in the summer of 2009, using a qualitative method with the objective of addressing the role of subsistence agriculture in rural development and the adoption of pluriactivity schemes. Semi-structured interviews were carried out with ejido authorities and community leaders, and participant observation with the aim of capturing and analyzing the relationship between economic activities in peasant households. From this, 78 peasant households were identified and a survey was applied; from their willingness and knowledge about the situation to be explored, they were selected under an opinion sample (Ruiz, 1999), to provide information about the variables and the relationships being studied. The data were processed with the SPSS software. The information was systematized and analyzed in function of the variables and the study relationships being suggested in this document. 


\section{TRANSFORMACIONES AGRARIAS Y AGRICULTURA familiar en la Cordillera del TeNTzo}

La cordillera del Tentzo se localiza en la parte sureste de la ciudad de Puebla. Es considerada como el inicio de la mixteca poblana, integrada por los municipios de Tzicatlacoyan, Cuautinchán, Tecali de Herrera y la parte sur del municipio de Puebla. El clima es templado seco con lluvias en verano, con una temperatura media anual de $15.4{ }^{\circ} \mathrm{C}$. La precipitación media anual es de $743 \mathrm{~mm}$; $90 \%$ ocurre entre los meses de mayo a octubre. Los suelos predominantes son Litosoles, Cambisoles y Xerosoles, caracterizados por su escasa profundidad y con alto contenido de piedras y carbonatos.

La morfología de la región se caracteriza por una serie de lomeríos, serranías y algunas planicies. Los primeros, con pendientes irregulares, ocupan la mayor superficie de la región de estudio y cruzan de norte a sur por la parte central, extendiéndose hacia el este. Las serranías con pendientes irregulares mayores de $10 \%$ se localizan en la parte sur oriental y norte; las planicies se ubican en la parte centro norte y este, y presentan pendientes de 0-2\%. Su geología consiste en rocas sedimentarias, principalmente calizas y lutitas.

En 1520 Cuautinchán, Tepeaca, Tecali, Tecamachalco y Quecholac fueron conquistadas por los españoles y los tlaxcaltecas. Hernán Cortés fundó "Segura de la Frontera" en Tepeaca, y la mayor parte de las tierras y sus habitantes fueron repartidos en encomiendas. Con la expansión de las haciendas los campesinos fueron sometidos al peonaje y al pago de una renta por los terrenos que ocupaban. Tecali se convirtió en reproductora de fuerza de trabajo para las fincas agrícolas españolas y regiones de mayor desarrollo agropecuario a través de migraciones estacionales, como fueron Xochiltenango, Cuapiaxtla, Toxtepec, Tecamachalco y Tehuacán o hacia la región de la tierra caliente en las fincas cañeras y cafetaleras de Veracruz (Olivera, 1978).

Durante la colonia y el porfiriato, el sistema agrario de la cordillera del Tentzo se especializó en una economía productora de trigo y la reproducción de fuerza de trabajo, sobre la base de la economía doméstica que subsidiaba a las haciendas con mano de obra temporal al ocuparla temporalmente sin asumir su reproducción total (Olivera, 1978). Este sistema agrario se fracturó con la revolución de 1910, bajo el mando regional de los zapatistas Vidal Romero y

\section{AgRARIAN TRANSFORMATIONS AND FAMILY AGRICULTURE IN THE Tentzo Mountain Range}

The Tentzo Mountain Range is located in the southeast part of the city of Puebla. It is considered to be the beginning of Puebla's Mixteca region, made up of the municipalities of Tzicatlacoyan, Cuautinchán, Tecali de Herrera and the southern part of the municipality of Puebla. The climate is temperate dry with summer rains, with a mean annual temperature of $15.4{ }^{\circ} \mathrm{C}$. The mean annual precipitation is $743 \mathrm{~mm}$; $90 \%$ occurs between the months of May and October. The predominant soils are Lithosols, Cambisols and Xerosols, characterized by their limited depth and high content of rocks and carbonates.

The morphology of the region is characterized by a series of hills, mountains and some plains. The first with irregular slopes occupy the greatest surface in the study region and they cross from north to south on the central part, extending to the east. The mountain chains with irregular slopes of more than $10 \%$ are located in the southern, eastern and northern parts; the plains are located in the central north and east, and present slopes of 0-2\%. The geology consists of sedimentary rocks, primarily limestone and lutites.

In 1520, Cuautinchán, Tepeaca, Tecali, Tecamachalco and Quecholac were conquered by the Spanish and the Tlaxcalteca. Hernán Cortés founded "Segura de la Frontera" in Tepeaca and the greater part of the lands and their inhabitants were distributed into encomiendas. With the expansion of the haciendas, peasants were subjected to peonage and to the payment of rent for the lands they occupied. Tecali became a reproducer of workforce for the Spanish agricultural plantations and for regions of greater agricultural/livestock development, such as Xochiltenango, Cuapiaxtla, Toxtepec, Tecamachalco and Tehuacán, or for the region of tierra caliente in the sugarcane and coffee plantations of Veracruz, through seasonal migrations (Olivera, 1978).

During the Colony and Porfiriato, the agrarian system in the Tentzo Mountain Range became specialized in an economy of wheat production and workforce reproduction, on the basis of the domestic economy that subsidized the haciendas with seasonal labor by occupying it temporarily without assuming its total reproduction (Olivera, 1978). This agrarian 
Dolores Damián. Con la reforma agraria se expropiaron los latifundios, transformando el régimen de la tenencia de la tierra de la gran propiedad agraria a pequeñas unidades productivas.

El reparto agrario en la región se expresó en el régimen de tenencia de la tierra. Actualmente, de 45076.05 hectáreas de superficie total de los municipios de la región, $57.5 \%$ es ejidal, $37.1 \%$ privada, $4.4 \%$ comunal, y $1.0 \%$ pública (INEGI, 2009). Las tierras que se repartieron en los ejidos fueron de mala calidad, cerriles, agostadero o de segunda, con baja capacidad productiva. Las tierras para cultivo son reducidas, sólo representan $24.5 \%$ del total; las predominantes son de agostadero, con $74.9 \%$ y $0.1 \%$ bosque, y $0.5 \%$ sin vegetación (INEGI, 2009).

El reparto agrario generó, como forma dominante, un sistema agrario de pequeñas explotaciones y trabajo familiar dirigido a la producción de autoconsumo, con maíz (Zea mays) y frijol (Phaseolus vulgaris L.), la cría de ganado caprino, la artesanía y la venta de la fuerza de trabajo. De acuerdo con el VII Censo Agropecuario, en 1991 existían 4982 unidades de producción rural (UPR), de las cuales $74.7 \%$ contaban con superficie de labor, con un tamaño promedio de 3.14 hectáreas. Asimismo, 7.9\% de las UPR poseían hasta cinco hectáreas y $21 \%$ restante tenía una superficie mayor a las cinco hectáreas (INEGI, 1994).

En las últimas décadas el tamaño de las UPR se redujo, fraccionando aún más la tierra, pero también se amplió la superficie agrícola, ambos procesos vinculados al crecimiento demográfico de la población. De acuerdo con el VIII Censo Agropecuario (INEGI, 2009), en 2007 se reportaron 6374 UPR, $27.9 \%$ más que en 1991, mientras las UPR con actividades agropecuarias se incrementaron $41.8 \%$ (5,276 UPR) y la superficie agrícola se aumentó $6.8 \%$, al pasar de 11684.3 a 12481.6 hectáreas. La superficie por UPR es de 2.4 hectáreas.

La ampliación de las áreas de cultivo y del fraccionamiento de la tierra expresa el interés de los campesinos por mantener la propiedad de la tierra como bien patrimonial social y económico, al representar un activo en la producción de alimentos e ingresos, así como una base a partir de la cual construye sus estrategias de reproducción social que, como señala Warman (2002: 95), "proporciona refugio y seguridad, ninguno en abundancia, ni siquiera con suficiencia, pero no tiene mejor sustituto para millones de campesinos". system was fractured with the Revolution of 1910, under the regional lead of Zapatistas Vidal Romero and Dolores Damián. With the agrarian reform, the large estates were expropriated, transforming the land ownership regime of large agrarian property into small productive units.

The agrarian distribution in the region was expressed in the land ownership regime. Currently, out of 45076.05 hectares of total surface in the municipalities of the region, $57.5 \%$ is ejido, $37.1 \%$ private, $4.4 \%$ communal and $1.0 \%$ public (INEGI, 2009). The lands that were distributed into ejidos were of bad quality, mountainous, pasturelands or second-rate, with low productive capacity. The lands for cultivation are reduced, only representing $24.5 \%$ of the total; the predominant are pasturelands, with $74.9 \%$ and $0.1 \%$ forest, and $0.5 \%$ with no vegetation (INEGI, 2009).

The agrarian distribution generated an agrarian system of small-scale farms and family work directed at auto consumption production, as a form of domination, with maize (Zea mays) and bean (Phaseolus vulgaris L.), goat breeding, handcrafts and the sale of workforce. According to the $7^{\text {th }}$ Agricultural and Livestock Census, in 1991 there were 4982 rural production units (RPU), of which $74.7 \%$ had farming surface, with an average size of 3.14 hectares. Likewise, $7.9 \%$ of the RPUs had up to five hectares and the remaining $21 \%$ had a surface larger than five hectares (INEGI, 1994).

In recent decades the size of the RPUs has reduced, fractioning the land further, but the agricultural surface also increased, both processes linked to the demographic growth of the population. According to the $8^{\text {th }}$ Agricultural and Livestock Census (INEGI, 2009), in 20076374 RPUs were reported, $27.9 \%$ more than in 1991, while the RPUs with agricultural/ livestock activities increased in $41.8 \%$ (5276 RPUs) and the agricultural surface increased $6.8 \%$, going from 11684.3 to 12481.6 hectares. The surface per RPU is 2.4 hectares.

The increase in cultivation areas and the fractioning of land express an interest by peasants for maintaining land ownership as a social and economic patrimonial good, by representing an asset in the production of food and income, as well as a basis from which their strategies for social reproduction are built, which, as Warman (2002: 95) suggests, "provide refuge and security, none in abundance, not 
La valoración social de la tierra por los campesinos es contraria a la perspectiva planteada por la reforma al Artículo 27 Constitucional de 1992 y la Ley Agraria, que conciben a la tierra como un factor productivo que debería ser liberado de restricciones para su incorporación al mercado. En la exposición de motivos de la iniciativa a la reforma del Artículo 27 Constitucional, se consideró al minifundio en un trabajo para el desarrollo asociado a "niveles de vida inaceptables", y se argumentó que en el minifundio se presentaban estancamientos y deterioro técnico que se traducían en producción insuficiente, baja productividad, relaciones de intercambio desfavorables, y niveles de vida inaceptables. Esta valoración deja sin posibilidad normativa el desarrollo agrícola de la pequeña propiedad basada en el trabajo familiar; sin embargo, la evidencia empírica muestra la persistencia social de estos sectores. El reconocimiento de la permanencia de la pequeña explotación agraria representa el primer paso para la definición; desde las políticas públicas de una vía de desarrollo agrícola, como una opción para la producción de alimentos y otros bienes y servicios que la agricultura proporciona.

Hasta la actualidad, la producción agrícola en la región se ha mantenido con pequeñas variantes, con los cultivos que se observan en el Cuadro 1. La producción es dominada por los cultivos básicos, generalmente sembrados como múltiples, como son maíz (Zea mays) asociado con frijol (Phaseolus vulgaris L.) y/o haba (Vicia faba) y calabaza (Cucurbita maxima Duch), que permite aprovechar al máximo las pocas tierras disponibles y hacer frente a la aleatoriedad de even with sufficiency, but there is no better substitute for millions of peasants".

The social valuation of land by peasants is contrary to the perspective set out by the reform to Constitutional Article 27 in 1992 and the Agrarian Law, which conceives land as a productive factor that should be freed from restrictions for its incorporation into the market. In the exposition of motives for the reform initiative to Constitutional Article 27, in a study for its development smallholdings were considered associated to "unacceptable levels of life", and it was argued that smallholdings present stagnation and technical deterioration that translate into insufficient production, low productivity, unfavorable exchange relations, and unacceptable levels of life. This valuation leaves the agricultural development of small property based on family work without normative possibility; however, the empirical evidence shows the social persistence of these sectors. The recognition of the permanence of small agrarian farms represents the first step for the definition as an option for food production and other goods and services that agriculture provides, from the stance of public policies in a development path for agriculture.

Until today, agricultural production in the region has been maintained with small variation, with the crops shown in Table 1. Production is dominated by basic crops, generally sown as multiples, such as maize (Zea mays) associated with bean (Phaseolus vulgaris L.) and/or broad bean (Vicia faba) and squash (Cucurbita maxima Duch), allowing to take advantage to the maximum of the few lands available, and to face the randomness of rains. In addition,

Cuadro 1. Superficie sembrada y cultivos en municipios de la Cordillera del Tenzo, 2011.

Table 1. Surface sown and crops in the municipalities of the Tentzo Mountain Range, 2011.

\begin{tabular}{|c|c|c|c|c|c|}
\hline \multirow{2}{*}{ Cultivos } & \multicolumn{3}{|c|}{ Superficie sembrada (ha) } & \multirow{2}{*}{$\begin{array}{l}\text { Total } \\
\text { (ha) }\end{array}$} & \multirow{2}{*}{ Porcentajes } \\
\hline & Cuautinchán & Tecali de Herrera & Tzicatlacoyan & & \\
\hline Maíz grano & 4144.0 & 3320.0 & 3100.0 & 10564.0 & 80.1 \\
\hline Frijol & 190.0 & 205.0 & - & 395.0 & 3.0 \\
\hline Agave mezcalero & 20.0 & 32.0 & 150.0 & 202.0 & 1.5 \\
\hline Forrajes & 100.0 & 373.0 & 280.0 & 753.0 & 5.7 \\
\hline Hortalizas & 13.0 & 669.7 & - & 682.7 & 5.2 \\
\hline Trigo grano & 95.0 & 115.0 & 286.0 & 496.0 & 3.8 \\
\hline Otros & 10.0 & 60.0 & 20.0 & 90.0 & 0.7 \\
\hline Total & 4572.0 & 4774.7 & 3836.0 & 13182.7 & 100.0 \\
\hline
\end{tabular}

Fuente: SIAP (2012). Anuario Estadístico de la Producción Agrícola 2011. • Source: SIAP (2012). Statistical Annual Directory of Agricultural Production 2011. 
las lluvias. Además, se cultiva el trigo (Triticum aestivum) y algunas hortalizas bajo condiciones de riego, particularmente en las comunidades de los municipios de Tecali y Cuautinchán, que se encuentran en las inmediaciones del valle de Tepeaca. El maíz es cultivado en $80.1 \%$ de la superficie y, en menor medi$\mathrm{da}$, forrajes y hortalizas, que son cultivos con mayor rentabilidad económica, con el aprovechamiento de escorrentías y pequeñas obras de riego, o la búsqueda de nuevas alternativas productivas, como es el caso del agave mezcalero (Angustifolia Haw) en el municipio de Tzicatlacoyan.

La actividad agrícola es realizada en tierras erosionadas, poco profundas, con $\mathrm{pH}$ alto y precipitaciones pluviales erráticas, que tiene como consecuencia una agricultura de baja productividad. Los rendimientos de maíz y frijol son menores de $800 \mathrm{~kg} \mathrm{ha}^{-1}$ y $300 \mathrm{~kg}$ $\mathrm{ha}^{-1}$, respectivamente.

La ganadería se dedica a la producción y manejo de pequeños rumiantes en pastoreo (ovinos y caprinos), animales de traspatio (aves y porcinos), y animales de trabajo (bovinos y equinos). La ganadería dedicada a la cría de pequeńos rumiantes es la de mayor importancia económica, criados para la venta de animal adulto en un sistema agrosilvopastoril. El rebaño ganadero está formado por 3.9 cabezas de bovinos y 2.7 equinos (ambos animales de trabajo), 15.4 cabezas de ovinos, y 27.4 cabezas de caprinos (Vargas, 2003).

El sistema agrosilvopastoril presiona sobre el agostadero, ocasionando el desequilibrio en la reposición natural de los pastos y la vegetación, profundizando la erosión de los suelos, la explotación forestal, principalmente la extracción de leña, ocasiona un proceso similar.

El cambio de uso de suelo y la sobreexplotación han ocasionado pérdidas de áreas importantes de la superficie arable por erosión hídrica; la vegetación nativa ha disminuido drásticamente, de acuerdo con los entrevistados. Las prácticas tradicionales de conservación de suelo, como el descanso de la tierra, bordos y terrazas, no han sido capaces de evitar la progresiva degradación de la tierra, ya que la presión demográfica ha reducido el número de años que se deja la tierra sin cultivar. Las terrazas presentan descuido al no conservarse de manera óptima y la protección a través de bordos no se ha hecho de forma generalizada. Los terrenos agrícolas muy degradados son destinados al pastoreo o dejan de utilizarse en la wheat (Triticum aestivum) and some vegetables are cultivated under irrigation conditions, particularly in communities of the municipalities of Tecali and Cuautinchán, which are located near the Tepeaca Valley. Maize is cultivated in $80.1 \%$ of the surface and, to a lesser degree, fodder and vegetables, which are crops with higher economic profitability, with the use of runoffs and small irrigation works; or, there is a search for new productive alternatives, as is the case of agave for mezcal (Angustifolia haw) in the municipality of Tzicatlacoyan.

Agricultural activity is carried out in erosion lands, shallow, with high $\mathrm{pH}$ and erratic rain precipitation, which have the consequence of being of low-productivity agriculture. The maize and bean yields are lower than $800 \mathrm{~kg} \mathrm{ha}^{-1}$ and $300 \mathrm{~kg} \mathrm{ha}^{-1}$, respectively.

Livestock is devoted to the production and management of small ruminants in grazing (sheep and goats), backyard animals (birds and pigs), and work animals (bovine and equine). The livestock production devoted to breeding small ruminants is the one of most economic importance, for the sale of adult animals in an agricultural/forestry/pastoral system. The livestock flock is formed by 3.9 heads of bovine and 2.7 equine (both work animals), 15.4 heads of sheep, and 27.4 heads of goats (Vargas, 2003).

The agricultural/forestry/pastoral system exerts pressure on the pastureland, causing an unbalance in the natural reposition of grass and vegetation, deepening soil erosion; while forest exploitation, mainly the extraction of wood, causes a similar process.

The changes in land use and overexploitation have caused losses of important areas from the arable surface from hydric erosion; native vegetation has decreased dramatically, according to those interviewed. The traditional practices of soil conservation, such as resting the land, edges and terraces, have not been capable of avoiding the progressive degradation of the land, since the demographic pressure has reduced the number of years that land is left without cultivating. The terraces show neglect since they are not conserved in optimal conditions, and the protection with edges has not been done in a generalized manner. Very deteriorated agricultural lands are destined to grazing or they cease to be used for agricultural/livestock production. The deterioration of resources places at 
producción agropecuaria. El deterioro de los recursos pone en entredicho la reproducción de los sistemas de producción agropecuarios.

Las características agroecológicas de la Cordillera del Tentzo establecen los límites a la diversificación y productividad agrícola, pero también a la obtención de ingresos económicos. De ello puede derivar que la familia campesina privilegie la obtención de recursos sobre la conservación de recursos, afectando las condiciones de producción. Es plausible que bajo estas condiciones la lógica productiva de la agricultura se imponga sobre la restauración de los recursos. Las exigencias inmediatas de la reproducción social se imponen sobre los ciclos ecológicos, rompiendo los delicados equilibrios ambientales. De esta manera, más que una causa de la destrucción o degradación de los ecosistemas, la pobreza es un mecanismo por medio del cual ciertas condiciones objetivas de sobrevivencia se transforman en acciones que causan degradación ambiental.

\section{Poblamiento y POBREZA RURAL EN la Cordillera del Tentzo}

El sistema agrario de pequeñas unidades productivas agropecuarias de baja productividad y autoconsumo de la cordillera del Tentzo, enfrenta elevadas tasas de crecimiento demográfico y una condición de pobreza rural.En los últimos 60 años los municipios casi han cuadriplicado su población. En 1950 la población fue de 10558 habitantes y en 2010, de 40185 personas. El municipio de Tecali de Herrera concentró $63.1 \%$ de la población; Cuautinchán, $24.7 \%$; y Tzicatlacoyan, $12.2 \%$ (CONAPO, 1993; INEGI, 2011).

La población de la región se encuentra dispersa en 44 comunidades y pequeñas rancherías; sólo la cabecera municipal del municipio de Tecali y la junta auxiliar de Ahuatepec tienen más de tres mil habitantes. En el ámbito regional, Tecali es el principal centro económico, especialmente de talleres artesanales de ónix y mármol, e infraestructura de servicios. Las cabeceras municipales concentran los servicios y en torno a ellos se estructuran las pequeńas comunidades dispersas, que son "al mismo tiempo símbolo del mundo rural -con respecto a las ciudades propiamente dichas- y la más pequeña unidad del sistema urbano- con respecto al asentamiento rural más disperso" (Bataillon, 1997:56). risk the reproduction of the agricultural/livestock production systems.

The agro-ecological characteristics of the Tentzo Mountain Chain establish the limits to diversification and agricultural production, but also to the obtaining of economic income. From this it can be derived that the peasant family favors obtaining resources over the conservation of resources, affecting the conditions for production. It is plausible that the productive logic of agriculture imposes upon the restoration of resources under these conditions. The immediate demands of social reproduction are imposed over ecological cycles, breaking delicate environmental equilibria. Thus, beyond a cause for the destruction or degradation of ecosystems, poverty is a mechanism by which certain objective conditions of survival are transformed into actions that cause environmental degradation.

\section{RURAL POPULATION AND POVERTY IN THE Tentzo Mountain Range}

The agrarian system of small agricultural/livestock production units of low productivity and auto consumption in the Tentzo Mountain Chain faces high rates of demographic growth and a condition of rural poverty. In the last 60 years the municipalities have nearly quadrupled their population. In 1950 the population was 10558 inhabitants and in 2010, there were 40185 residents. The municipality of Tecali de Herrera concentrated $63.1 \%$ of the population; Cuautinchán, $24.7 \%$; and Tzicatlacoyan, $12.2 \%$ (CONAPO, 1993; INEGI, 2011).

The population in the region is dispersed into 44 communities and small rancherias; only the municipal township of the municipality of Tecali and the auxiliary council of Ahuantepec have more than three thousand inhabitants. In the regional scope, Tecali is the main economic center, especially of onyx and marble artisanal workshops, and services infrastructure. The municipal townships concentrate services and around them the small disperse communities are structured, which are "at the same time symbol of the rural world - with regards to the cities proper - and the smallest units of the urban system - with regards to the most disperse rural settlements" (Bataillon, 1997:56).

The relationships and resources that are woven upon the agrarian basis of the Tentzo Mountain 
Cuadro 2. Porcentajes de población en condiciones de pobreza en la Cordillera del Tentzo, 2010.

Table 2. Percentages of the population in conditions of poverty in the Tentzo Mountain Range, 2010.

\begin{tabular}{lcccccc}
\hline & $\begin{array}{c}\text { Población } \\
\text { total }\end{array}$ & $\begin{array}{c}\text { Pobreza } \\
(\%)\end{array}$ & $\begin{array}{c}\text { Pobreza extrema } \\
(\%)\end{array}$ & $\begin{array}{c}\text { Pobreza } \\
\text { moderada } \\
(\%)\end{array}$ & $\begin{array}{c}\text { Vulnerable por } \\
\text { carencia social } \\
(\%)\end{array}$ & $\begin{array}{c}\text { No pobre y no } \\
\text { vulnerable } \\
(\%)\end{array}$ \\
\hline Estatal & 5794763 & 61.2 & 16.7 & 44.5 & 22.0 & 11.3 \\
Cuautinchán & 9922 & 77.7 & 26.5 & 51.1 & 20.3 & 1.2 \\
Tecali de Herrera & 25351 & 66.3 & 14.3 & 52.0 & 28.7 & 3.3 \\
Tzicatlacoyan & 4912 & 90.7 & 42.6 & 48.1 & 9.1 & 0.1 \\
\hline
\end{tabular}

Fuente: CONEVAL (2012). Source: CONEVAL (2012).

Las relaciones y recursos que se tejen sobre la base agraria de la cordillera del Tentzo por los hogares campesinos se expresan en pobreza. De acuerdo con los cálculos del Consejo Nacional de Evaluación de la Política de Desarrollo Social (CONEVAL), que se presentan en el Cuadro 2, la población de los municipios es pobre ${ }^{2}$ mayoritariamente, rebasando el porcentaje estatal de población en pobreza. El caso más agudo es el municipio de Tzicatlacoyan, con $90.7 \%$ de la población en pobreza y $42.6 \%$ en pobreza extrema. Sólo reducidos sectores de la población que no rebasan $3.3 \%$ no son pobres, como el caso del municipio de Tecali de Herrera.

Las condiciones de pobreza de la región obligan a la integración de la fuerza laboral a otros ámbitos de mayor dinamismo económico en la búsqueda de empleos e ingresos. Es común que la población de la región se integre como fuerza laboral a la ciudad de Puebla, Distrito Federal, el sureste mexicano, y los Estados Unidos de Norteamérica. Particularmente, es relevante que la población se traslade diariamente a la ciudad de Puebla a laborar, por su cercanía y la existencia de vías de comunicación construidas a principios de la década de 1990.

La diversificación laboral de los hogares campesinos se expresa en la composición de la población económicamente activa (PEA) de la región. En el Cuadro 3 se presenta la PEA dedicada a las actividades primarias entre 1990 y el 2010; en este periodo la distribución laboral se transformó con el declive relativo de la PEA del sector primario y el incremento de las actividades secundarias y terciarias, sin que ello signifique la reducción absoluta de las actividades primarias, pues éstas se han incrementado en los municipios de Tecali de Herrera y Cuautinchán, mientras que en el municipio de Tzicatlacoyan muestra un franco retroceso o decadencia en términos absolutos y relativos. La permanencia de
Range by the peasant households are expressed in poverty. According to the calculations by the National Council for Evaluation of the Social Development Policy (Consejo Nacional de Evaluación de la Política de Desarrollo Social, CONEVAL), presented in Table 2 , the population of the municipalities is mainly poor $^{2}$, more so than state percentage of population in poverty. The most acute case is the municipality of Tzicatlacoyan, with $90.7 \%$ of the population in poverty and $42.6 \%$ in extreme poverty. Only small sectors of the population, no further than $3.3 \%$, are not poor, as in the case of the municipality of Tecali de Herrera.

Conditions of poverty in the region force the integration of the workforce into other areas of greater economic dynamism, in the search for employment and income. It is common for the population in the region to be integrated as workforce in the city of Puebla, in Distrito Federal, the southeast of México and the United States. Particularly, it is relevant that the population travels daily to the city of Puebla to work, because of its nearness and the existence of roads built at the beginning of the 1990s.

Labor diversification of peasant households is expressed in the composition of the economically active population (EAP) in the region. Table 3 presents the EAP devoted to primary activities between 1990 and 2010; during this period the labor distribution was transformed with the relative decline of EAP in the primary sector and the increase in secondary and tertiary activities, without this meaning the absolute reduction of the primary activities, for these have increased in the municipalities of Tecali de Herrera and Cuautinchán, while in the municipality of Tzicatlacoyan they show a marked relapse or decadence in absolute and relative terms. The permanence of the population in primary activities, 
Cuadro 3. Evolución de la PEA del sector primario en los municipios de la Cordillera del Tentzo 1990-2010. Table 3. Evolution of the EAP in the primary sector in the municipalities of the Tentzo Mountain Range 1990-2010.

\begin{tabular}{|c|c|c|c|c|c|c|c|c|}
\hline \multirow{2}{*}{ Municipios } & \multicolumn{3}{|c|}{ PEA del sector primario } & \multicolumn{3}{|c|}{$\begin{array}{c}\text { PEA del sector Primario } \\
(\%)\end{array}$} & \multirow{2}{*}{$\begin{array}{l}\text { Crecimiento } \\
\text { relativo porcen- } \\
\text { tual de la PEA } \\
\text { entre } 1990 \mathrm{y} \\
2010\end{array}$} & \multirow{2}{*}{$\begin{array}{l}\text { Crecimieto abso- } \\
\text { luto porcentual de } \\
\text { la PEA entre } 1990 \\
\text { y } 2010\end{array}$} \\
\hline & 1990 & 2000 & 2010 & 1990 & 2000 & 2010 & & \\
\hline Cuautinchán & 715 & 766 & 766 & 61.6 & 36.8 & 22.3 & -39.3 & 7.1 \\
\hline Tecali de Herrera & 1048 & 1403 & 1262 & 31.5 & 25.6 & 15.7 & -15.8 & 20.4 \\
\hline Tzicatlacoyan & 973 & 966 & 603 & 67.7 & 53.0 & 30.4 & -37.3 & -38.0 \\
\hline
\end{tabular}

Fuente: Elaboración propia con base en los Censos de Población y Vivienda 1990, 2000 y 2010 (INEGI, 1992, 2001 y 2011). • Source: Author's elaboration based on the Population and Housing Census 1990, 2000 and 2010 (INEGI, 1992, 2001 and 2011 ).

la población en actividades primarias, especialmente en la agricultura, expresa la importancia social de la actividad en un contexto de reducidas opciones económicas y se manifiesta, como se señaló anteriormente, en el incremento de la superficie cultivada y el número de unidades de producción rural.

Las relaciones constitutivas de la distribución espacial de la pobreza ${ }^{3}$, en la cordillera del Tentzo están vinculadas con la particularidad histórica, social, económica y ambiental del territorio y la forma en que se extendieron las relaciones sociales y económicas dominantes en el espacio, ocasionando un desarrollo económico desigual y desequilibrado.

Las características agrarias y de recursos de la cordillera del Tentzo limitan dinámicas económicas de inversión e inserción en los mercados, asumiendo un rol de reproductoras de fuerza de trabajo, condición profundizada por políticas inequitativas que no favorecen ni la producción y ni las actividades económicas. La inversión pública es escasa, con un bajo impacto en la generación de infraestructura. El consumo es débil y no concurren flujos importantes de mercancías y de capital. El capital productivo, financiero y comercial se orienta hacia las ramas productivas y regiones con mayor rentabilidad y ventajas comparativas y competitivas.

\section{LA AGRICULTURA FAMILIAR Y LA PLURIACTIVIDAD}

En el contexto social, económico y ambiental antes señalado, los hogares campesinos, a partir de sus miembros, articulan acciones y estrategias de reproducción social ${ }^{4}$, utilizando los bienes y activos de los que disponen para la obtención de ingresos económicos para su reproducción socioeconómica, en una tensión entre especially agriculture, expresses the social importance of the activity within a context of reduced economic options, and is manifested, as was pointed out earlier, in the increase of surface cultivated and the number of rural production units.

The constitutive relationships of the spatial distribution of poverty ${ }^{3}$, in the Tentzo Mountain Range, are linked to the historical, social, economic and environmental particularities of the territory, and the way in which the dominating social and economic relationships expanded in the space, causing an unequal and unbalanced economic development.

The agrarian and resource characteristics of the Tentzo Mountain Range limit the economic dynamics of investment and insertion into markets, assuming a role of reproducers of workforce, a condition deepened by unequitable policies that do not favor production or economic activities. Public investment is scarce, with a low impact on the generation of infrastructure. Consumption is weak and important flows of merchandise and capital do not concur. The productive, financial and commercial capital is directed towards productive fields and regions with greater profitability and comparative and competitive advantages.

\section{FAMILY AGRICULTURE AND PLURIACTIVITY}

Within the social, economic and environmental context mentioned before, peasant households articulate actions and strategies of social reproduction ${ }^{4}$ from their members, using the goods and assets that they have available for obtaining economic income for their socioeconomic reproduction, in tension between the environmental possibilities and limits, the local dynamics linked to agriculture, and the insertion into labor markets. 
las posibilidades y limitantes ambientales, las dinámicas locales vinculadas a la agricultura, y la inserción en mercados laborales.

El ingreso económico está formado por el ingreso económico agrícola, ganadero y no agrícola. Cada uno de éstos aporta un volumen diferenciado de recursos, que con la información de campo se calcularon en porcentajes de ingreso con los siguientes resultados: ingreso no agrícola, $68.7 \%$; agrícola, $3.7 \%$; y ganadero, $27.6 \%$. De acuerdo con los ingresos, la agricultura es marginal y está dirigida a una producción de autoconsumo; el ingreso no agrícola es el dominante y le sigue la ganadería. Esta composición del ingreso promedio para los hogares campesinos es heterogénea socialmente para cada hogar campesino, de acuerdo con el tamaño del predio, la estructura de cultivos, la rentabilidad de la producción, la fuerza laboral disponible y los ingresos no agrícolas, entre otros elementos.

Las actividades agropecuarias de la cordillera del Tentzo no son suficientes para la reproducción social y económica de los hogares campesinos, más aún con un mayor fraccionamiento de la tierra y crecimiento demográfico, lo que obliga a la pluriactividad económica. La pluriactividad de los hogares campesinos es resultado de la condición marginal de la agricultura; entre otros, por la fragilidad ambiental, la escasez de la tierra, los procesos vinculados con el mercado de trabajo y la relación entre lo urbano y rural, factores que condicionan la reproducción social y espacial del campesinado.

$\mathrm{El}$ ingreso neto agrícola generalmente no es suficiente para recuperar los costos de producción. La racionalidad de la producción agrícola, en condiciones de fragilidad ambiental, obedece fundamentalmente a la obtención de alimentos para el autoconsumo y residuos de cosecha para la ganadería, sostenida por la fuerza laboral familiar, que no es sometida a relaciones salariales y permite asumir el proceso de producción agropecuario en condiciones deficitarias. ${ }^{5}$

El ingreso económico global de los hogares campesinos descansa en la división del trabajo familiar y la aportación de sus miembros en las actividades agropecuarias y las no agrícolas, que movilizan y utilizan los activos con los que cuenta, entre ellos tierra, fuerza de trabajo y redes de relaciones sociales para su reproducción social y económica. La disposición de fuerza laboral familiar en condiciones de marginalidad productiva constituye uno de los
Economic income is made up of agricultural, livestock and non-agricultural income. Each one of these contributes a differentiated volume of resources, which with the field information were calculated in percentages of income with the following results: non-agricultural income, $68.7 \%$; agricultural, $3.7 \%$; and livestock, $27.6 \%$. According to the income, agriculture is marginal and it is directed at production for auto consumption; the non-agricultural income dominates and is followed by livestock production. This composition in the average income for the peasant household is socially heterogeneous for each peasant household, based on the size of the piece of land, the crop structure, the profitability of production, the available workforce and the non-agricultural income, among other elements.

Agricultural/livestock activities in the Tentzo Mountain Range are not sufficient for the social and economic reproduction of peasant households, and even more so with a greater fractioning of land and demographic growth, which forces them into economic pluriactivity. Pluriactivity of the peasant households is the result of the marginal condition of agriculture; among others, because of environmental fragility, scarcity of land, processes linked to the labor market, and the relationship between urban and rural aspects, factors that condition the social and spatial reproduction of peasants.

The net agricultural income is generally not sufficient to recover the costs of production. The rationality of agricultural production, under conditions of environmental fragility, fundamentally obeys obtaining food for auto consumption and harvesting residues for livestock, sustained by the family labor that is not subjected to salary relations and allows assuming the process of agricultural/ livestock production under deficit conditions. ${ }^{5}$

The global economic income of peasant households rests on the division of family labor and the contribution by its members in agricultural/ livestock and non-agricultural activities, which mobilize and utilize the assets available, among them land, workforce and social relationship networks, for their social and economic reproduction. The disposition of family workforce under conditions of productive marginality constitutes one of the main assets to overcome the limitations of capital and productive means. 
activos principales para superar las limitaciones de capital y medios productivos.

Los empleos no agrícolas que desempeñan los miembros de los hogares campesinos son generalmente informales, inestables, marginales y flexibles, que no garantizan seguridad social, ni ingresos o salarios estables y permanentes. Entre los empleos que desempeñan se encuentran jornaleros, albañiles, jardineros, carpinteros, plomeros, choferes, domésticos, artesanos y pequeños comerciantes, ya sea en el país o en los Estados Unidos.

Para las anteriores actividades, los trabajadores se articulan desde las comunidades con ámbitos de mayor dinamismo económico a través de redes sociales para proporcionar una fuerza de trabajo barata y flexible, en una inclusión laboral inestable y precaria. De acuerdo con las encuestas aplicadas, $67 \%$ de los hogares campesinos manifestó que de dos a tres de sus miembros laboran en actividades no agrícolas, $22 \%$ de uno a dos, y $11 \%$ uno de sus miembros. El promedio de tiempo que laboran al año es de ocho meses y sólo $7 \%$ manifestó algún tipo de seguridad social en estos empleos.

Los recursos económicos que se generan en las actividades no agrícolas se dirigen a consumo, educación, compra de bienes, construcción, y mejoría de la casa habitación y las actividades agropecuarias. Las transferencias de recursos económicos de las actividades no agrícolas a las agrícolas representan, en promedio, $14 \%$ de los ingresos totales anuales en $80 \%$ de los hogares campesinos entrevistados, al considerar que es una actividad que les permite tener maíz, rastrojo e ingresos con la venta de ganado, además de "no dejar la tierra sin cultivar".

Los hogares campesinos sobre la base del uso integral de los activos que poseen, tangibles e intangibles, desempeñan un conjunto de actividades agrícolas y no agrícolas en forma integral y complementaria para su reproducción socioeconómica. Ninguna de las actividades en forma aislada explica su funcionamiento. El debilitamiento o eliminación de los activos y actividades económicas limitan su capacidad de reproducción y muy probablemente conducen a una mayor pobreza.

La pluriactividad a su vez está ocasionando la reorganización social de los hogares campesinos, obligando a las mujeres de la cordillera del Tentzo a participar en la dirección de los procesos de producción ante la ausencia del jefe de familia, con
The non-agricultural jobs that members of the peasant households carry out are generally informal, unstable, marginal and flexible, and they do not guarantee social security nor stable and permanent income or salaries. Among the jobs carried out there are day laborers, bricklayers, gardeners, carpenters, plumbers, drivers, domestic servants, artisans and small-scale business owners, whether in the country or in the United States.

For these activities, workers from the communities are articulated with areas of greater economic dynamism through social networks, to provide a cheap and flexible workforce, in labor inclusion that is unstable and precarious. According to the surveys applied, $67 \%$ of the peasant households manifested that two to three of their members work in nonagricultural activities, $22 \%$ one to two, and $11 \%$ one of their members. The average of time that they work during the year is eight months and only $7 \%$ manifested some type of social security from those jobs.

Economic resources that are generated in nonagricultural activities are directed at consumption, education, purchasing goods, construction and improvement of the home, and agricultural activities. Transference of economic resources from nonagricultural activities to agricultural ones represent, in average, $14 \%$ of the total annual income in $80 \%$ of the peasant households interviewed, when considering that it is an activity that allows them to have maize, fodder and income from livestock sales, in addition to "not leaving land without cultivating".

Peasant households perform a set of agricultural and non-agricultural activities in an integral and complementary manner on the basis of the integral use of the assets they possess, tangible and intangible, for their socioeconomic reproduction. None of the activities explain their functioning in an isolated manner. The weakening or elimination of assets and economic activities limit their capacity for reproduction and very likely lead to greater poverty.

Pluriactivity in its turn is causing the social reorganization of household peasants, forcing the women of Tentzo Mountain Range to participate in the direction of production processes in the absence of the head of the household, with the consequent feminization of agriculture and rural life, thus reconfiguring gender and generational relationships. 
la consecuente feminización de la agricultura y de la vida rural, reconfigurando las relaciones de género y generacionales.

La valoración social de la agricultura que realizan los hogares campesinos de la cordillera del Tentzo no es apoyada por las políticas públicas de desarrollo agrícola. A partir de la política de ajuste estructural, instrumentada hacia finales de la década de 1980, se eliminaron apoyos y servicios de fomento productivo a la agricultura en regiones de fragilidad ambiental por su baja productividad. El crédito, seguro agrícola, asistencia técnica e investigación agronómica, entre otros factores, se orientaron hacia las regiones y a los productores que se señalaron con "potencial productivo"; para las regiones con fragilidad ambiental se establecieron acciones de combate a la pobreza (Téllez, 1994). Los sectores sociales en condiciones de pobreza ciertamente requieren de programas de ataque directo a las condiciones de pobreza, pero también el atender y fomentar su capacidad productiva a partir de instrumentos de política acordes con las condiciones de la región.

En este marco, a través de la agricultura, los hogares campesinos de la Cordillera del Tentzo mantienen un espacio de reproducción social y económica, pero en condiciones sumamente precarias. La formación regional se especializa, articula y subordina a otras regiones, pero su viabilidad se ve amenazada por las condiciones en las que se desarrolla la agricultura y el deterioro del ambiente. En la trayectoria territorial se han tejido relaciones de desigualdad social, donde el campesinado se reproduce socialmente sobre el trabajo agropecuario y la pluriactividad, generalmente en trabajos flexibles y de baja remuneración, con procesos de inclusión/exclusión en los mercados laborales. La inclusión laboral es generalmente inestable, precaria y cambiante, insuficiente para la reproducción social y económica de los trabajadores y sus dependientes económicos.

\section{LA AGRICULTURA FAMILIAR EN EL DESARROLLO RURAL TERRITORIAL}

La lectura sobre las transformaciones rurales funda perspectivas normativas del desarrollo rural. El ascenso de la pluriactividad y la multifuncionalidad del territorio han dado pauta a considerar que los motores del desarrollo rural no se encuentran en la agricultura. Por ejemplo, se han sistematizado las
The social valuation of agriculture that peasant households perform in the Tentzo Mountain Range is not supported by public policies for agricultural development. Stemming from the policy of structural adjustment, implemented at the end of the 1980s, supports and services for productive promotion to agriculture were eliminated in regions of environmental fragility because of their low productivity. Credit, agricultural insurance, technical assistance and agronomic research, among other factors, were directed towards the regions and producers that were signaled to have "productive potential"; for the regions with environmental fragility, actions were established to combat poverty (Téllez, 1994). The social sectors in conditions of poverty certainly require programs that tackle conditions of poverty directly, but they also need to deal with and foster their productive capacity from policy instruments in agreement with the region's conditions.

Within this framework, through agriculture, the peasant households in the Tentzo Mountain Range maintain a space of social and economic reproduction, but under extremely precarious conditions. The regional formation specializes, articulates and subordinates other regions, but its viability is threatened by the conditions under which agriculture develops and environmental deterioration. In the territorial trajectory, relationships of social inequity have been woven, where peasants reproduce socially on agricultural/livestock work and pluriactivity, generally in flexible and underpaid jobs, with processes of inclusion/exclusion in the labor markets. The labor inclusion is generally unstable, precarious and changing, insufficient for the social and economic reproduction of workers and their economic dependents.

\section{FAMILY AGRICULTURE IN TERRITORIAL RURAL DEVELOPMENT}

The interpretation of rural transformations establishes normative perspectives for rural development. The ascent of pluriactivity and multifunctionality of the territory have given rise to considering that the motors of rural development are not found in agriculture. For example, the possible lessons and pertinence of the European LEADER proposal in Latin America ${ }^{6}$ have been systematized 
posibles lecciones y la pertinencia del planteamiento europeo LEADER en América Latina ${ }^{6}$ (Pérez y Caballero, 2003; Saraceno, 2006; Sumpsi, 2006). También se ha formulado el planteamiento del desarrollo rural territorial, con el análisis de los vínculos entre ruralidad y territorio.

El territorio se ha asumido como una categoría central en el análisis y las propuestas de desarrollo rural, al considerarlo como una construcción social con una identidad social, económica y cultural propia. La elaboración conceptual del desarrollo rural territorial 7 es propuesto "como un proceso de transformación productiva e institucional en un espacio rural determinado, cuyo fin es reducir la pobreza rural" (Schejtman y Berdegué (2003:31). La trasformación productiva tiene como finalidad la articulación de la economía del territorio a mercados dinámicos. El desarrollo institucional tiene los propósitos de estimular y facilitar la interacción y la concertación de los actores locales entre sí y con los agentes externos relevantes (Schejtman y Berdegué, 2003).

Esta perspectiva coloca a la competitividad territorial como el elemento central del enfoque, la cual enfrenta una condición poco propicia en ámbitos territoriales con economías agrarias poco diversificadas y desarticuladas de mercados dinámicos, donde la inversión privada y pública no concurren por las limitadas o nulas ventajas comparativas y competitivas, como es el caso de la cordillera del Tentzo. Mientras el desarrollo institucional en la dirección de la concertación de actores locales y agentes externos, afronta el mayor desafío en las relaciones inequitativas y diferenciales de poder entre los actores sociales, que delimita la apropiación de rentas, recursos y la participación social.

El desarrollo rural territorial amplía las perspectivas de desarrollo rural, que debe ser evaluado a partir de las condiciones particulares de los territorios y su multidimensionalidad, que implica su área, sus recursos y las relaciones que lo transforman (Fernandes, 2009); del incremento de los precios de los alimentos en el mercado internacional y las estrategias de reproducción del campesinado, las cuales comprenden el uso integral de los medios de vida y la integración de las actividades agrícolas y no agrícolas.

En este marco, la cordillera del Tentzo se concibe como una formación socio-territorial que desempeña una multiplicidad de funciones sociales, culturales y ambientales, vinculadas al desarrollo agrícola y no
(Pérez and Caballero, 2003; Saraceno, 2006; Sumpsi, 2006). The approach of territorial rural development has also been formulated, with the analysis of links between the rural scope and territory.

Territory has been assumed as a central category in the analysis of and proposals for rural development, by considering it a social construct with a social, economic and cultural identity of its own. The conceptual elaboration of territorial rural development ${ }^{7}$ is suggested "as a process of productive and institutional transformation in a specific rural space, whose goal is to reduce rural poverty" (Schejtman and Berdegué (2003:31). Productive transformation has the goal of articulating the territory's economy with dynamic markets. Institutional development has the goals of stimulating and facilitating the interaction and agreement of local actors among each other and with the relevant external agents (Schejtman and Berdegué, 2003).

This perspective places territorial competitiveness as the central element of the approach, facing a barely favorable condition in territorial scopes with slightly diversified agrarian economies and disarticulated from dynamic markets, where private and public investment do not concur because of the limited or null comparative and competitive advantages, as is the case of the Tentzo Mountain Range. At the same time, the institutional development in the direction of the agreement of local actors and external agents faces the greatest challenge in the unequal and differential power relations among social actors, which limit the appropriation of profit, resources and social participation.

Territorial rural development broadens the perspectives for rural development, which should be evaluated from the particular conditions of the territories and their multidimensionality, implicating their area, resources and the relationships that transform them (Fernandes, 2009); of the increase in prices of food in the international market and the strategies for reproduction of peasants, which cover the integral use of means of livelihood and integration of agricultural and non-agricultural activities.

Under this framework, the Tentzo Mountain Range is conceived as a socio-territorial formation that performs a multiplicity of social, cultural and environmental functions, linked to agricultural and non-agricultural development. The productive 
agrícola. El aporte productivo y territorial de la agricultura al desarrollo rural no es antagónico a las actividades no agrícolas, pues las actividades económicas son integrales y complementarias con la utilización y el aprovechamiento de los recursos tangibles e intangibles de los que disponen los hogares campesinos.

Las actividades agrarias en la región funcionan con severas restricciones, aprovechando las condiciones que le ofrece el entorno para diversificar las actividades y obtener rentas complementarias. No obstante, el desarrollo agrícola no es suficiente para la reproducción de los hogares campesinos, pero su abandono en un contexto incierto y agravado por factores globales, como el cambio climático, el alza de los precios de los alimentos y la crisis energética, ponen en riesgo la seguridad alimentaria y la superación de la pobreza (Graziano et al., 2008).

Para los hogares campesinos de la cordillera del Tentzo, las actividades agropecuarias tienen un carácter multifuncional al comprender funciones ambientales, económicas, sociales y culturales. La agricultura genera la cohesión e integración de las actividades económicas y la organización del territorio. Económicamente aporta y produce alimentos y forrajes para la ganadería, así que su eliminación implicaría la reducción de los ingresos económicos. Regionalmente, el abandono de éstas ocasionaría el despoblamiento y tendría aún más impacto sobre el empleo en las ciudades o la migración internacional, donde tampoco existen las condiciones más propicias para la inserción de la fuerza de trabajo en el mercado laboral.

Un sistema agropecuario sustentable para la cordillera del Tentzo puede contribuir a regular la fuerza de trabajo, la seguridad alimentaria y el cuidado de los recursos y el medio ambiente, aspectos fundamentales para la viabilidad de la región.

La FAO y el BID (2007) sostienen que la agricultura familiar sigue siendo uno de los sectores más extendidos y dinámicos en las áreas rurales; consideran que su importancia no ha sido lo suficientemente reconocida ni valorada desde el punto de vista de las políticas públicas en los países de América Latina y El Caribe. Esta perspectiva es necesaria; las condiciones de la economía y el comercio agroalimentario mundial indican serios desequilibrios que permiten prever desajustes en la oferta de alimentos. El futuro de la oferta mundial de alimentos puede ser incierto: la creciente escasez de recursos, los mayores riesgos generados por el cambio climático, más altos precios and territorial contribution of agriculture to rural development is not antagonistic to the nonagricultural activities, since economic activities are integral and complementary with the use and exploitation of tangible and intangible resources that are available to peasant households.

Agrarian activities in the region function with severe restrictions, taking advantage of the conditions that the environment offers to diversify activities and obtain complementary profits. However, agricultural development is not enough for the reproduction of peasant households, but its abandonment within an uncertain context and aggravated by global factors, such as climate change, the rise in food prices and the energetic crisis, places food security and overcoming poverty at risk (Graziano et al., 2008).

For peasant households in the Tentzo Mountain Range, agricultural/livestock activities have a multifunctional character since they cover environmental, economic, social and cultural functions. Agriculture generated the cohesion and integration of economic activities and the organization of the territory. It contributes economically and produces food and fodder for livestock production, so that its elimination would imply the reduction of economic income. Regionally, its abandonment would cause loss of population and it would have further impact on employment in the cities or international migration, where the most favorable conditions for the insertion of workforce into the labor market also do not exist.

A sustainable agricultural/livestock system for the Tentzo Mountain Range can contribute to regulate the workforce, food security, and the care for resources and the environment, fundamental aspects for the viability of the region.

The FAO and BID (2007) maintain that family agriculture continues to be one of the most widespread and dynamic sectors in rural areas; they consider that its importance has not been sufficiently recognized or valued from the point of view of public policies in Latin American and Caribbean countries. This perspective is necessary; the conditions of the global economy and agro-food commerce indicate grave unbalances that allow foreseeing imbalances in the food offer. The future of the global food offer can be uncertain: the growing scarcity of resources, the higher risks generated by climate change, the higher prices for 
para la energía, la demanda por biocombustibles, y dudas acerca de la velocidad del progreso técnico, tienen todos implicaciones para el progreso de la agricultura (Banco Mundial, 2008).

\section{ConClusiones}

Las relaciones agroecológicas, sociales y de poder hacen de la cordillera del Tentzo una región de reproducción social de fuerza de trabajo y pobreza. Las tensiones sociales que se generaron históricamente en diversas etapas, particularmente durante la colonia y la revolución de 1910, dieron pauta a profundas transformaciones agrarias que marcaron las tendencias de su evolución sin lograr romper el ciclo de pobreza de la población.

Los campesinos de la región lucharon por acceder a la tierra y por tener una base material que les permitiera su reproducción e inclusión social y productiva en el sistema económico, pero esta base es frágil, en fraccionamiento, de baja productividad, en constante erosión, e insuficiente para su reproducción socioeconómica, por lo que la migración temporaria fue desde siempre una constante para la obtención de ingresos económicos.

Con la inserción en los mercados laborales de los miembros de los hogares campesinos, la base agraria de la reproducción social cambió, pero sin abandonar la agricultura, integrando las actividades agrícolas y no agrícolas para cierta estabilidad estructural, de tal manera que la permanencia regional del campesinado no es sólo resultado de las transformaciones agrarias, sino también de procesos vinculados con el mercado de trabajo. Estas relaciones le permiten, a su vez, trasferir recursos de los ingresos no agrícolas a la agricultura, valorando socialmente y productivamente a la agricultura para aprovechar los recursos de los que dispone en la producción de alimentos y ganado, generando ingresos y trabajo.

La población de los municipios de la región se incrementó en las últimas décadas. Las migraciones temporales no significaron despoblamiento; entre otros aspectos, por las características de los mercados de trabajo de flexibles e inestables. Los campesinos han mantenido la posesión de la tierra como un activo y patrimonio social, económico y cultural, pero también la han fraccionado, mientras que la superficie de labor y el número unidades productivas con actividad agropecuaria se han incrementado. energy, the demand for biofuels, and the doubts about the speed of technical progress, all have implications for the progress of agriculture (Banco Mundial, 2008).

\section{Conclusions}

The agro-ecologic, social and power relations make Tentzo Mountain Range a region of social reproduction of workforce and poverty. The social tensions that were generated historically during various stages, particularly during the Colony and the 1910 Revolution, gave rise to profound agrarian transformations that marked the trends of its evolution without managing to break the cycle of poverty in the population.

Peasants in the region fought to gain access to land and to have a material basis that would allow their reproduction and social and productive inclusion in the economic system, but this base is fragile, under fractioning, of low productivity, in constant erosion, and insufficient for its socioeconomic reproduction, which is why temporary migration has always been a constant for obtaining economic income.

With the insertion into labor markets of the members of peasant households, the agrarian base of social reproduction changed, although without abandoning agriculture, integrating agricultural and non-agricultural activities for certain structural stability, so that the regional permanence of peasants is not only the result of agrarian transformations, but also of processes linked to the labor market. These relationships allow, in their turn, to transfer resources from non-agricultural income to agriculture, valuing agriculture socially and productively to take advantage of the resources that are available for the production of food and livestock, generating income and work.

The population in the municipalities of the region increased in recent decades. Temporary migrations did not represent a decrease in population; among other aspects, because of the characteristics of the labor markets of being flexible and unstable. Peasants have maintained the possession of land as an asset and social, economic and cultural patrimony, but they have also fractured it, while the farming surface and the number of productive units with agricultural/ livestock activity have increased.

Peasant agriculture is an activity and component for a regional rural development path, based on the 
La agricultura campesina es una actividad y componente para una vía de desarrollo rural regional, basada en los recursos locales y en las estrategias de reproducción de los hogares campesinos, pues no representa una oposición con las actividades no agrícolas; su abandono profundizaría la emigración y la pobreza.

Un sistema agrario sustentable puede contribuir al desarrollo rural de la Cordillera del Tentzo en los siguientes aspectos: a) regular las migraciones de la fuerza laboral; b) contribuir a la seguridad alimentaria, empleo e ingresos, y c) el cuidado de los recursos y el medio ambiente. Sin embargo, esta perspectiva es insuficiente para superar la pobreza. Son necesarias acciones convergentes bajo una visión multisectorial y territorial, en el corto, mediano y largo plazo, que incluya la articulación de la política social y agrícola.

\section{Notas}

1"El proceso de "desagrarización" se refiere a una disminución progresiva de la contribución de las actividades agrícolas a la generación de ingreso en el medio rural, así como una creciente migración y envejecimiento de su población" (Escalante et al., 2007:89). - The "process of deagrarization" refers to a progressive decrease in the contribution of agricultural activities to the generation of income in the rural environment, as well as growing migration and ageing of its population (Escalante et al., 2007:89).

${ }^{2}$ La Ley General de Desarrollo Social señala que la pobreza debe medirse utilizando 8 dimensiones: ingreso, rezago educativo, acceso a la salud, acceso a la seguridad social, calidad y espacios de la vivien$\mathrm{da}$, acceso a servicios básicos en la vivienda, acceso a la alimentación, y grado de cohesión social. $\bullet$ The General Law for Social Development (Ley General de Desarrollo Social) establishes that poverty should be measured using 8 dimensions: income, educational backwardness, access to health, access to social security, housing quality and space, access to basic services in the household, access to food, and degree of social cohesion.

${ }^{3}$ En México en las zonas rurales reside $60.7 \%$ de la población en pobreza extrema y $46.1 \%$ de los moderadamente pobres, en 2004, incrementándose la pobreza rural en las últimas dos décadas a partir de la segunda reforma agraria (RIMISP, 2012). • In local resources and the strategies for reproduction of peasant households, since it does not represent an opposition to non-agricultural activities; its abandonment would deepen migration and poverty.

A sustainable agrarian system can contribute to rural development in the Tentzo Mountain Range in the following aspects: a) to regulate migrations of workforce; b) to contribute to food security, employment and income; and c) to care for resources and the environment. However, this perspective is insufficient to overcome poverty. Convergent actions under a multisectorial and territorial vision are necessary, in the short, middle and long term, including the articulation of the social and agricultural policy.

- End of the English version -

México, $60.7 \%$ of the population in extreme poverty and $46.1 \%$ of the moderately poor resided in rural zones, in 2004, with rural poverty increasing during the past two decades since the second agrarian reform (RIMISP, 2012).

${ }^{4}$ El concepto de sistema de estrategias de reproducción social, entendidas como "conjunto de prácticas fenomenalmente muy diferentes, por medio de las cuales los individuos y las familias tienden, de manera consciente o inconsciente, a conservar o a aumentar su patrimonio, y correlativamente a mantener o mejorar su posición en la estructura de las relaciones de clase" (Bourdieu, 1988:122). - The concept of system of social reproduction strategies, understood as "a set of practices that are phenomenally very different, through which individuals and families tend, consciously or unconsciously, to conserve or increase their patrimony, and correlatively, to maintain or improve their position in the structure of class relations" (Bourdieu, 1988:122).

${ }^{5}$ De acuerdo con Vergopulos (1979) esta lógica campesina no sería el resultado de los elementos residuales del pasado precapitalista sino, por el contrario, tendría un origen contemporáneo al capitalismo moderno. En realidad, es el capitalismo moderno el que hace posible, tanto histórica como teóricamente, la aparición de la lógica no capitalista de la unidad familiar en la producción agrícola. According to Vergopulos (1979) this peasant logic would not be the result of residual elements of the 
pre-capitalist past, but rather, on the contrary, would have an origin contemporary to modern capitalism. In truth, it is modern capitalism that makes the apparition of the non-capitalist logic of the family unit in agricultural production possible, both historically and in theory.

${ }^{6} \mathrm{Se}$ trata de conferir mayor importancia a: i) la dimensión territorial en oposición a la sectorial, así como a las funciones y servicios prestados por la agricultura más allá del aspecto productivo; ii) los vínculos entre las pequeñas ciudades y el campo circundante, y la relación entre desarrollo urbano y rural; iii) la complementariedad entre la agricultura y otras ocupaciones; iv) la función residencial de las áreas rurales; v) la integración de las áreas rurales a los mercados y los procesos de globalización, lo que destaca la importancia de la competitividad territorial frente a la puramente empresarial o sectorial; vi) el potencial económico que ofrecen los activos ligados al territorio, de tipo geográfico, histórico, cultural, etcétera; y vii) la participación en las políticas y programas de desarrollo rural de los diversos agentes involucrados y la concertación entre ellos (Pérez y Caballero, 2003). - It is about conferring greater importance to: i) the territorial dimension in opposition to the sectorial, as well as to the functions and services provided by agriculture beyond the productive aspect; ii) the connections between small cities and the surrounding countryside, and the relation between urban and rural development; iii) the complementarity between agriculture and other occupations; iv) the residential function of rural areas; v) the integration of rural areas to the markets and globalization processes, highlighting the importance of territorial competitiveness in face of the solely entrepreneurial or sectorial; vi) the economic potential that assets linked to the territory offer, of geographic, historical, cultural, etc., types; and vii) the participation in rural development policies and programs of the various agents involved and the agreement between them (Pérez and Caballero, 2003).

${ }^{7}$ Teóricamente, el enfoque del desarrollo territorial se funda en la noción de distritos industriales planteada por Bagnasco, en la de clusters introducida por Porter, y en la del desarrollo económico local (Sumpsi, 2006). - Theoretically, the approach of territorial development is founded on the notion of industrial districts set out by Bagnasco, on that of clusters introduced by Porter, and that of local economic development (Sumpsi, 2006).

\section{Literatura Citada}

Banco Mundial. 2008. Informe sobre el Desarrollo Mundial 2008: Agricultura para el desarrollo. Banco Mundial, Mundi-Prensa y Mayol Ediciones. Bogotá.

Bataillon, Claude. 1997. Espacios mexicanos contemporáneos. Fondo de Cultura Económica y Colegio de México. México.

Bourdieu, Pierre. 1988. La Distinción. Criterio y bases sociales del gusto. Taurus. Madrid.

Carton de Grammont, Hubert. 2007. Las organizaciones "campesinas" y la transición política en México (fuerzas y debilidades). In: Observatoire des Amériques. Disponible: http://www.er.uqam.ca/nobel/ieim/article-oda.php3?id_article $=3918$

Carton de Grammont, Hubert. 2009. La desagrarización del campo mexicano. In: Convergencia. Núm. 5.

Castells, Manuel. 2006. La era de la información. Fin de milenio. Vol. 3. Alianza Editorial. Madrid.

CONAPO (Consejo Nacional de Población). 1993. La población de los municipios de México, 1950-1990. México.

CONEVAL (Consejo Nacional de Evaluación de la Política de Desarrollo Social). 2012. Medición de la pobreza. Disponible: http://web.coneval.gob.mx/Medicion/ Paginas/Medici\%C3\%B3n/Pobreza\%202012/Anexoestad\%C3\%ADstico-pobreza-2012.aspx

De Janvry, Alain y Elizabeth Sadoulet. 2004. Hacia un enfoque territorial del desarrollo rural. Universidad de California (Sede de Berkeley). Preparado para el Cuarto Foro Temático Regional de América Latina y el Caribe Cosechando Oportunidades: Desarrollo Rural en el Siglo 21. Costa Rica. 19 a 21 de octubre de 2004.

Dirven, Martine. 2004. El empleo rural no agrícola y la diversidad rural en América Latina. In: Revista de la CEPAL. Núm. 83.

Escalante, Roberto, Horacio Catalán, Luis Miguel Galindo y Orlando Reyes. 2007. Desagrarización en México: tendencias actuales y retos hacia el futuro. In: Cuadernos Desarrollo Rural. Vol. 4, Núm. 59

FAO/BID (Organización de las Naciones Unidas para la Agricultura y la Alimentación y Banco Interamericano de Desarrollo. 2007. Políticas para la Agricultura Familiar en América Latina y el Caribe. Disponible: http://www.rlc.fao.org/es/ desarrollo/fao-bid/pdf/politicasaf.pdf

Fernandes, Bernardo. 2009. Territorio, teoría y política. In: Fabio Lozano Velázquez y Juan Guillermo Medina (eds). Las configuraciones de los territorios rurales en el siglo XXI. Pontificia Universidad Javeriana. Colombia.

Graziano, José, Sergio Gómez, y Rodrigo Castañeda. 2008. Boom agrícola y persistencia de la pobreza rural en América Latina”. In: Revista Española de Estudios Agrosociales y Pesqueros. Núm. 218.

INEGI (Instituto Nacional de Estadística, Geografía e Informática). 1992. XI Censo General de Población y Vivienda, 1990. México.

INEGI (Instituto Nacional de Estadística, Geografía e Informática). 1994. VII Censo Agropecuario 1991. México. 
INEGI (Instituto Nacional de Estadística, Geografía e Informática). 2001. XII Censo General de Población y Vivienda, 2000. México.

INEGI (Instituto Nacional de Estadística, Geografía e Informática). 2009. VIII Censo Agrícola, Ganadero y Forestal 2007. México.

INEGI (Instituto Nacional de Estadística, Geografía e Informática). 2011. Censo de Población y Vivienda 2010. México. Resultados definitivos. Disponible: www.inegi.org.mx (4 de marzo de 2011).

Kay, Cristóbal. 2007. Algunas reflexiones sobre los estudios rurales en América Latina. In: Revista Iconos. Núm. 29.

Link, Thierry. 2001. El campo en la ciudad: reflexiones en torno a las ruralidades emergentes. In: Revista Estudios Agrarios. Núm. 17.

Olivera, Mercedes. 1978. Pillis y macehuales: las formaciones sociales y los modos de producción de Tecali del siglo XII al XVI. CIESAS-Ediciones de la Casa Chata. México.

Pérez, Antonio, y José María Caballero. 2003. La Nueva Ruralidad en Europa y su interés para América Latina. FAO. Roma.

Pérez, Edelmira. 2001. Hacia una nueva visión de lo rural. In: Norma Giarracca (coord) ¿Una nueva ruralidad en América Latina? CLACSO. Argentina.

Pérez, Edelmira. 2005. Desafíos sociales de las transformaciones del mundo rural: nueva ruralidad y exclusión social. In: Seminario Chile rural: un desafío para el desarrollo humano. Disponible: www.desarrollohumano.cl/otraspub/pub11/informe\%20rural.pdf

Rello, Fernando. 1998. La ciudad intermedia, un factor de desarrollo regional. El caso de Zamora, México. In: Revista Políticas Agrícolas. Número especial.

Rimisp (Centro Latinoamericano para el Desarrollo Rural). 2012. Pobreza y desigualdad. Informe Latinoamericano 2011. Santiago, Chile.
Ruiz, José Ignacio. 1999. Metodología de la investigación cualitativa. Universidad de Deusto. España.

Saraceno, Elena. 2006. Experiencia europea de desarrollo rural. Memoria del Seminario Internacional Desarrollo rural y el sector agroalimentario: Estrategias de Futuro. SAGARPA, INCA, IICA, FAO. México.

Schejtman, Alexander. 1999. Las dimensiones urbanas en el desarrollo rural. In: Revista de la CEPAL. Núm. 67.

Schejtman, Alexander y Julio Berdegué. 2003. Desarrollo territorial rural. In: Rubén Echeverría (ed). Desarrollo territorial rural en América Latina y el Caribe: manejo sostenible de recursos naturales, acceso a tierras y finanzas rurales. Washington, D. C. Banco Interamericano de Desarrollo.

Schejtman, Alexander, y Julio Berdegué. 2008. Desigualdad y pobreza como desafíos para el desarrollo rural territorial. In: Revista Española de Estudios Agrosociales y Pesqueros. Núm. 218.

SIAP (Servicio de Información Agroalimentaria y Pesquera). 2012. Anuario Estadístico de la Producción Agrícola 2011. México.

Sumpsi, José María. 2006. Experiencias Desarrollo rural con enfoques territorial en la Unión Europea y América Latina y perspectivas. In: Revista Española de Estudios Agrosociales y Pesqueros. Núm. 209.

Téllez, Luis. 1994. Campo. In: Arturo Warman (Comp.). La política social en México, 1989-1994. Fondo de Cultura Económica. México.

Vargas, Samuel. 2003. Análisis y desarrollo del sistema de producción agrosilvopastoril caprino para carne en condiciones de subsistencia de Puebla, México. Tesis doctoral. Universidad de Córdoba. España.

Vergopulos, Kostas.1979. El papel de la agricultura familiar en el capitalismo. In: Cuadernos agrarios. Núm. 9.

Warman, Arturo. 2002. El campo mexicano en el siglo XX. Fondo de Cultura Económica. México. 